\title{
AC 2010-1080: GROWING PAINS: CHINESE ENGINEERING EDUCATION DURING THE LATE QING DYNASTY
}

Junqiu Wang, Purdue University

Nathan McNeill, Purdue University

Sensen Li, Purdue University, West Lafayette 


\title{
Growing pains: Chinese engineering education in the late Qing Dynasty
}

\begin{abstract}
With the continued advancement of engineering as a global field of activity, it becomes critical to understand engineering education from a more global perspective. Specifically, Chinese engineering education has been experiencing radical transformation and development over the past twenty years, especially in tandem with rapid economic development. However, few studies have examined the current status of engineering education in China, as well as the historical path of development of a modern Chinese engineering education system. How was a Confucian educational tradition transformed into a modern educational system?

To better understand some of the driving forces behind the current Chinese engineering education system, we need to take a historical journey back to the origins of modern engineering education in China. In this paper, we specifically examine engineering education during the preRepublic era, or late Qing Dynasty, from the 1840s to 1911. Based on analysis of archival sources and other relevant historical documents, this paper describes a series of key historical events and discusses how a range of political, social, and economic conditions likely influenced the formation of a new engineering education system during this period. This paper reports on three main research themes: 1) How were engineers trained immediately prior to the formation of a modern engineering education system in China? 2) What were the driving forces that initiated the reformation of the engineering education system? and 3) How was a Westernized engineering education system fused with a long tradition of Confucian-dominated education? The paper concludes with some reflections about how the legacy of this transformation lives on in the contemporary context of Chinese engineering and engineering education.
\end{abstract}

\section{Introduction}

Chinese engineering education has been experiencing tremendous expansion in the past 20 years, in parallel with rapid economic growth in China. According to statistical data from the Chinese Ministry of Education, around 15,000 Ph.D. degrees, more than 100,000 master's degrees, and more than 700,000 bachelor's degrees (Some researchers estimate that these numbers are inflated, nevertheless, the actual numbers are very large.) in engineering were awarded in $2009^{1}$. These numbers represent an increase of more than four times the number of degrees awarded in $1998^{1,2}$. For comparison, the number of engineering bachelor's degrees awarded in the United States has increased at a much slower rate in the past ten years, with 61,000 graduates in 1999 and 74,000 in $2008^{2}$. Within the engineering education community, there is growing interest in the current status of engineering education in China due to the globalization of the engineering profession $^{3}$.

As has been well documented elsewhere, the engineering profession has often historically served larger interests, especially those associated with nation-states and private sector employers 5 . Yet this begs the question: Who are China's engineers, what is their history, and what are their local and global trajectories? To begin answering such questions, we believe it is necessary to look at 
the origins of modern Chinese engineering education, starting in the mid-1800s. In this paper, we focus especially on three higher education institutions founded during the late Qing dynasty in the latter half of the $19^{\text {th }}$ century that played important roles in the formation of modern Chinese engineering education.

The account that follows is a historical narrative describing the conditions that led to the adoption of modern, Western style engineering education in China. This paper is based upon both primary and secondary sources. Primary sources include reprints of archival documents from the institutions discussed in this paper. Secondary sources include books written in English and published by university affiliated publishing houses.

\section{Pre-modern "engineering education"}

China has had a strong technological tradition in many areas, including metallurgy, astronomy, ceramics, and architecture ${ }^{4}$. However, several historical factors slowed the advancement of Chinese engineering and technology especially during the latter half of the Qing dynasty beginning during the 1840s and ending in 1911. Among these factors social hierarchy and the traditional apprenticeship training system for technical professions were the most prominent.

Social hierarchy. In the traditional Chinese value system dominant during the dynastic periods of Chinese history, a man with technical skills did not enjoy high social status. A clear distinction was made between mental work and manual labor and a corresponding distinction between the ruling classes and those who were ruled. Social hierarchy was divided into four levels. The top level, or rank, was reserved for government officials and civil servants who achieved their positions through a series of national examinations. In order to succeed in the examinations, students typically spent more than ten years memorizing classic literary works. This system was similar to higher education in Britain before the introduction of modern engineering education in that country in the $1800 \mathrm{~s}^{5}$. The second rank in the Chinese social hierarchy was occupied by farmers who enjoyed a relatively high position in society because they were responsible for feeding the nation. Technical professions held the third rank in the social hierarchy and merchants were in the lowest rank ${ }^{6}$. Because of the relatively low rank of technical professions in the social hierarchy, the motivation for pursuing such a career in traditional China was very low ${ }^{7}$.

The apprenticeship training system. Members of the technical professions, or artisans, were trained through a hands-on apprenticeship system. In carpentry, for example, an apprentice learned carpentry skills by working with a master carpenter. The apprentice watched and helped the master work. The master explained every move he made to the apprentice. Normally, the master would provide accommodation and food for his apprentices, and in exchange, the apprentices would work for the master for free until they achieved enough skills to work independently. After that, the former apprentice would become a master and take in apprentices of his own. This social class included craftsmen such as architects, woodworkers, and blacksmiths. Traditionally, there were two pathways to a technical career. One was through a master-student relationship; the other was through a father-son relationship. Because of the relatively low social status of technical professions, technical training was not institutionalized in China. The technical professions were not considered to be learned professions, and so very few 
technical books were published. Although a few books on Western technology and science were published in China, Western learning was not highly regarded and so the books did not enjoy wide circulation ${ }^{8}$.

\section{Historical Context}

Historically, formal education in China focused on the study of literature, philosophy, and history in order to prepare students for the national civil service examinations. Success in the civil service examinations opened up a career among the ruling elite in the government bureaucracy. Preparation for the examinations focused particularly on the study of the Confucian classics $^{9,10}$. Based on the teachings of Confucius, a philosopher who lived in the $5^{\text {th }}$ century BC, the Confucian classics where collections of writings by his disciples and other later commentators. Although perhaps not technically a religion, Confucianism provided a moral structure for society and elevated virtue over inherited status. An emphasis on meritocracy provided the philosophical foundation for the civil service examinations ${ }^{11}$. In theory anyone could take the civil service examinations and, if successful, increase their position in society. In reality only the wealthy could afford to adequately educate their sons for success in the examinations ${ }^{9}$. The examination system perpetuated the elevation of Confucian thought and the social stratification of certain professions. Success in the civil service examinations elevated a man above those who had to work with their hands. Mathematics, science, and technology were the tools of the merchant and artisan classes and were considered to be beneath the dignity of an educated $\operatorname{man}^{10}$. A classical Chinese education stressed intellectual refinement at the expense of practical skills, resulting in an educated class who were ill prepared to compete against Western powers who were seeking trade and influence in China during the 1800s. Several historical events prompted reform minded officials in the Qing government to call for educational reform and emphasize the need for education that was practical. They also cautiously advocated teaching Western science and technology ${ }^{7}$.

Opium Wars. During the 1700s and early 1800s demand for Chinese goods such as tea, silk, and porcelain was very high in Europe. The British East India Company was involved in much of the trade with China, and although Europe imported goods from China, China was not interested in buying European goods. The resulting trade imbalance meant that the British were sending virtually empty ships to China. The British were further frustrated by China's demand for payment only in silver. In order to balance trade, the British East India Company began smuggling opium into China and sold it in exchange for silver. Initially the Chinese government didn't pay much attention to the rapidly growing problem of opium addiction among its citizens. But by the early 1800 s the problem had become so serious that the government appointed a new governor of the southern port city of Canton with a mandate to deal with the problem. At the time, Canton was the only Chinese city that was open to foreign trade. Lin Zexu, the new governor tasked with eliminating the opium trade, seized more than 20,000 chests of opium from foreign traders in June of 1839. This action upset the British who, in 1840, sent troops from India to Southern China where they attacked Canton and other coastal cities ${ }^{11}$. The weapons of the Chinese were no match for the advanced guns, canons, and ships of the British, resulting in a humiliating defeat for the Chinese. After the war, China was forced to open up four port cities to British trade and cede control of the island of Hong Kong to England. 
Tensions continued to simmer and conflict erupted again in 1856 when Chinese officials in Canton searched a British ship suspected of carrying opium. This time British forces threatened the Chinese capital, Beijing. Conflict lasted until 1860 when the Chinese government was forced to open ten new port cities to foreign trade. China's defeat in the Second Opium War motivated the Qing government to begin a process of military modernization which in turn led to the establishment of several military academies. The goal of these academies was to not only to train officers, but to train students in the art of designing, making, and maintaining weapons and modern warships ${ }^{7}$.

Taiping Rebellion. In the 1840s, in rural Guandong province, a young man named Hong xiuquan failed the civil service exams three years in a row. Discouraged, and suffering from ill health, Hong began studying Christian religious tracts given to him by a relative. Hong began to have religious visions which lead him to believe that he was literally God's son and the younger brother of Jesus Christ. Hong soon became the leader of a religious cult and set up the Taiping Tianguo (太平天国), or Kingdom of Heavenly Peace, a utopian communal movement. This movement grew rapidly because it espoused egalitarianism and peasant emancipation. By 1850 the movement had turned militant resulting in full blown civil war. Hong led his armies north making the city of Nanjing capital of his new kingdom. The Qing government, lacking sufficient military strength, struggled for many years to put down the Taiping uprising. The war consequently lasted many years and resulting in millions of deaths ${ }^{13}$.

The proximity of Hong's volatile Heavenly Kingdom in Nanjing began to worry the Western powers in nearby Shanghai, so they set up a special military force to protect Shanghai from attack. It was with assistance from this special force that the Qing government was finally able to crush the rebellion in $1864^{12}$. It is ironic that the Qing government had to turn for help to the Western forces who had defeated them in 1860 during the Second Opium War. The Taiping uprising might have collapsed on its own due to internal turmoil, but the intervention of Western forces in the conflict again reminded the Chinese government of the inadequacy of its military to effectively deal with national threats.

First Sino-Japanese War. China was not the only Asian country affected by the military strength of Western countries who were plying their waters seeking trade and influence. Japan had begun modernizing its military, economy, infrastructure, and education system at about the same time as China. Japan had been forced to open up to foreign trade in 1854 after a show of force in Edo harbor (now Tokyo) by American warships lead by Commodore Matthew Perry ${ }^{14}$. Although Japan has the longest continuous dynasty in recorded history, throughout much of its history real power rested in the hands of shoguns, or military dictators. In 1867, several powerful clans forced the ruling shogun to resign and restored power to the emperor. This event has been called the Meiji restoration after the name of the new emperor who took power that year.

The new emperor and his government began a series of radical reforms, with particular emphasis on industrialization. The traditional social class of warriors, called "samurai," was abolished and a program of conscription for all males aged 21 was instituted. Steam ships and railroads were built and Western learning was emphasized. Japan also began to develop a large, modern navy and $\operatorname{army}^{13}$. At this time Korea was a vassal state of China. Japan saw Chinese influence in the Korean Peninsula as a potential threat, due to Korea's proximity to the Japanese islands. During 
the 1880s, Japan used episodes of civil unrest in Korea as an excuse to build up a troop presence on the peninsula to protect their interests ${ }^{14}$. Finally, in 1894, tensions in Korea between China and Japan erupted into war. The war was short and lasted less than six months. The Japanese quickly gained control of the Korean Peninsula, destroyed the Chinese navy, and pushed into Manchuria (now the northeastern Chinese provinces of Liaoning, Jilin, Heilongjiang, and a large part of Inner Mongolia) the homeland of the Qing emperors. The loss of Manchuria to the Japanese was a humiliation to the Qing government as was the destruction of its new navy. The campaign to modernize the Chinese military had been plagued by corruption. Because of poor pay, morale and discipline in the navy were weak and the ships had been poorly maintained.

China's loss of its navy to another Asian power again revealed China's vulnerability. If it could not protect itself against its neighbor, then it did not stand a chance of protecting itself against the much more advanced navies of the Western countries who were seeking influence in Asia. Defeat by Japan provided new support for reformers in China and resulted in much more widespread and rapid reforms in China ${ }^{14}$. Improving higher education and training engineers to support modernization, particularly of the military, had become imperative. Wei Yuan, a prominent philosopher and enlightenment thinker of the late Qing dynasty, proposed the ideology: "learn from the West to defend against the West"16. In the remainder of this paper, we look at three educational institutions which are representative of the reform efforts which emphasized Western technical and engineering training.

\section{The Tongwen Guan ( 同文館 )}

The Tongwen Guan was the first modern, Western style educational institution established by the Chinese government. "Tongwen Guan" is often translated as "School of Combined Learning", but "Foreign Language Institute" might be a more descriptive translation. Established in Beijing in 1862, the original purpose of this school was to prepare foreign language translators to work in China's diplomatic corps. Before the establishment of this institution, Chinese diplomats generally had to rely on foreigners to translate for them. The establishment of this school was a direct result of defeat in the Second Opium War. The government had been forced to open up ten new port cities and, as a result, diplomatic relations with Western countries had increased. The establishment of this school was an attempt at self-sufficiency so that China could address Western countries on an equal footing.

At the time of its founding, the Tongwen Guan was unable to find qualified Chinese instructors who were fluent in foreign languages, so foreign instructors had to be hired at great expense. At the time there were a number of European and American missionaries in China who were very fluent in Chinese and had been actively involved not only in translating religious works into Chinese, but also in the translation of secular works on philosophy, science, and technology.

Initially, the Tongwen Guan had three tracks of study: English, French, or Russian. In addition, all students were required to study the Chinese language and Confucian thought. The administrators felt that this was important for maintaining the moral character of the students. Students were to have examinations monthly, quarterly, and annually, and after three years they were to have a final examination ending their three year course of study. Students who 
successfully passed the graduation exam were awarded with a tutorship in the institution or official rank within the civil service.

In 1866, the Tongwen Guan made a radical departure from its original mandate by establishing a new department of mathematics and astronomy. This new department was established to teach Western science, but the terms "astronomy" and "mathematics" were chosen for its name because these were traditional Chinese subjects and would be less threatening to traditionalists in the government who feared moral corruption through instruction in Western subjects. The Chinese official who established the new program "argued that the manufacture abroad of machinery and armaments and even the movement of ships and armies were based upon astronomy and mathematics and that China must master these subjects if it was to be strong."7 The intention was obviously to teach the basics of Western science necessary for the development of a modern military.

After the establishment of the new department a serious debate raged over what kind of students to recruit. All of the current students in the institution had been recruited from among young scholars who had passed the civil service examinations. Conservatives in the government were concerned that Western learning would pollute the minds of those who had passed the civil service exam. They also viewed the proposed instruction for the new department as little more than training in the mechanical arts or trades and as such beneath the dignity of scholars of high social status. They felt that students for the new department should be recruited from among the lower classes of society. On the other side of the argument, the school administrators wanted to recruit students from the ranks of those who had passed the civil service exam because they wanted students of "superior intellect"7. They also argued that such students were less likely to be corrupted by Western teaching because they were already grounded in Confucian thought. The school administrators lost the struggle. By this time, however, similar language institutions had been established in Canton and Shanghai. So, the administration of the Tongwe Guan requested that these institutions send some of their best students for advanced studies in the new department in Beijing.

Because of difficulties in recruiting students, the Tongwen Guan never achieved a particularly large enrollment. Many students also struggled to find meaningful employment upon graduation. Despite these challenges, the Tongwen Guan was significant as China's first institution to offer training in Western science and technology. Although defeat in the First Sino-Japanese War revealed how inadequate this first attempt at Western education had been, the Tongwen Guan provided a valuable learning experience for future institutions. In 1902, the Tongwen Guan was absorbed into the newly established Imperial Capital University which subsequently became Peking University in $1912^{7}$.

\section{The Foochow Shipbuilding College (Fuzhou arsenal, 福州造船廠)}

In 1866, Zuo Zongtang, the governor of Fujian Province, sent a proposal to the Qing emperor suggesting that China design and build a modern naval fleet ${ }^{17}$. Zuo Zongtang, one of the most prominent generals in the late Qing Dynasty, had spent his career fighting against foreign incursion. He had been involved in both Opium Wars as well as the suppression of the Taiping Rebellion. Because of his experience fighting Britain and France in the Opium Wars he realized 
the importance of building a strong navy to defend China against expanding Western influence. In his proposal to the emperor, Zuo Zongtang also recognized the need to train officers and engineers to staff the new naval fleet. Consequently, Foochow Shipbuilding College was established with the aim of building a strong, modern navy. This can be considered the starting point of modern Chinese engineering education. Just as formal engineering education in France and the United States began in a military context, modern engineering education in China was driven by military needs ${ }^{17}$.

Foochow Shipbuilding College started with two departments, or divisions. The first division, or Qian Xue Tang (literally “forward school”, 前学堂) trained students in the design and manufacture of battleships, while the second division, or Hou Xue Tang (literally "rear school", 后学堂) trained students in navigation and ship maintenance. This second division was developed essentially for the training of naval officers. These two divisions consequently had very different educational goals and curricular structures.

At the time, it was believed that the French were more experienced in the design and construction of ships, thus the curriculum in the Qian Xue Tang was based on a French military school model. In this division the language of textbooks and instruction was French. Thus the Qian Xue Tang was also called "the Navy Shipbuilding School," or "French School". Whereas, in the Hou Xue Tang, a British educational model was employed as the British were believed to be the world navigation experts. Under the suggestion of Zuo Zongtang, Prosper Marie Giquel was appointed as the first supervisor of the Foochow Shipbuilding School. Giquel, a French military officer who had fought in the Second Opium War, had also served as a commander of the "Franco-Chinese force" that helped to put down the Taiping rebellion.

The Qian Xue Tang ${ }^{17}$. In the Qian Xue Tang ("forward school"), the educational goal was to train students to understand the different components of modern ships and their functions. The length of the program of study was five years. Unlike other schools in China at the time, students began their studies with theory before progressing to application oriented subjects. Students were taught French, arithmetic, cartography, physics, trigonometry and calculus during the first three years of the curriculum. In the last two years, students learned about ship structure and machine operation. Students in the school had to follow very strict disciplinary rules and academic performance was carefully monitored. Under the supervision of Giquel, the Qian Xue Tang initially enrolled 105 students. Of these, only 39 graduated in 1874 as six students had died and 60 had been expelled for various reasons. Table 1 lists the courses taught in the Qian Xue Tang.

In 1867, a second section of the Qian Xue Tang was opened to focus specifically on ship design. This section provided a much more hands-on education with students spending a part of each day working in an engine repair workshop. Students in this section were also taught French, arithmetic, geometry, and cartography.

In 1868, a third section of the Qian Xue Tang was opened to train ship building apprentices to work in the school's shipyard. These workers were trained in reading and making engineering drawing, calculating shapes, volumes, and the weights of steam engines, and various other technical skills. Apprentices working in the shipyard took classes from 7:30 to 9:00 each evening in arithmetic, geometry, design and the structure of steam engines. Apprentices were required to 
take three exams each year. Those who passed all of the exams became official workers in the shipyard. Those who excelled in exams were "upgraded" into the original course of study in the Qian Xue Tang where they became fulltime students and received much more training in science.

Table 1. The courses of the Qian Xue Tang.

\begin{tabular}{|l|l|}
\hline $\begin{array}{l}\text { Foreign } \\
\text { Languages }\end{array}$ & French (all the textbooks were in French), English \\
\hline Basic sciences & $\begin{array}{l}\text { Arithmetic, trigonometry, analytic geometry, calculus, physics and } \\
\text { mechanics }\end{array}$ \\
\hline Major courses & $\begin{array}{l}\text { Engineering Cartography; the manufacture and structure of steam engines; } \\
\text { manufacturing of ship hulls }\end{array}$ \\
\hline
\end{tabular}

The Hou Xue Tang. Students in the Hou Xue Tang ("rear school") could choose from two majors: navigation, and ship maintenance. The course of study for the two majors in this division was three and a half years. The courses of study for these majors are found in Tables 2 and 3 . All of the studies in this division were carried out aboard real battleships rather than in a classroom.

Table 2. The courses of Hou Xue Tang navigation major.

\begin{tabular}{|l|l|}
\hline $\begin{array}{l}\text { Foreign } \\
\text { Languages }\end{array}$ & English (all the textbooks were in English) \\
\hline Basic sciences & Arithmetic, geometry, calculus, spherical trigonometry \\
\hline Major courses & Naval astronomy, meteorology, geography \\
\hline
\end{tabular}

Table 3. The courses of Hou Xue Tang ship's engineer major.

\begin{tabular}{|l|l|}
\hline $\begin{array}{l}\text { Foreign } \\
\text { Languages }\end{array}$ & English (all the textbooks were in English) \\
\hline Basic sciences & Arithmetic, geometry, calculus, spherical trigonometry \\
\hline Major courses & Structure of steam engines, maintenance of steam engines \\
\hline
\end{tabular}


When Foochow Shipbuilding College was founded in 1867, it had been 120 years since the first formal engineering school, the Ecole Nationale des Ponts et Chaussées, was founded in France. In France, students were required to take three years of preparation courses in math and science, as well as master basic subjects before entering into engineering practice. The Foochow Shipbuilding College followed the French model by placing emphasis on learning math and science first followed by specialized technical courses and industrial practice. In the United States, West Point and the U.S. Naval Academy also adopted the French military school model. Just as in the Foochow Shipbuilding College, a Frenchman and graduate of the Ecole Polytechnique, helped establish the civil and military engineering programs at West Point ${ }^{5}$.

Foochow Shipbuilding College trained many experts in military ship building and navigation. Most of the graduates took up critical positions in the China's North Pacific Fleet.

\section{Peiyang University (in pinyin - Beiyang University, 北洋大学 )}

In 1895, Sheng Xuanhuai, a customs official in the port city of Tianjin, received sanction from the Emperor to found Peiyang University, the first Chinese educational institution to fully adopt a Western university education model and train engineers in a way that would look familiar today. Sheng Xuanhuai was active in the Self-strengthening Movement which originated in Tianjin. China's defeat in the First Sino-Japanese War lent a real urgency to this movement which advocated learning from the West so that China could ultimately strengthen its military and protect itself against further encroachment from Japan and Western powers. Peiyang University acted as a model for the founding of many of other early Western style universities in China.

At its founding, Peiyang University hired many foreign professors who drew up the overall education plan of the university, designed the courses that were to be taught, and selected the textbooks to be used. Furthermore, the university purchased scientific equipment directly from the United States to stock its laboratories. The university also subscribed to more than 100 Western scientific and engineering journals in an effort to keep faculty and students up-to-date with the latest knowledge in their academic fields ${ }^{15}$.

Peiyang University had two programs of study: a college-preparatory program and an undergraduate program. Both were four year programs. To meet the needs of national development and the development of national self-reliance, departments of civil engineering, metallurgical engineering, and mining were established. In 1897, a railway engineering department was established to satisfy the growing demand for railway construction. In 1906, French and Russian translation courses were created to meet diplomatic needs. Thus, students could have more opportunities to access western information and knowledge ${ }^{18}$.

Peiyang University advocated a learner-centered teaching style that emphasized practical application and creative abilities. Because of this, students who chose to study applied, sciences such as engineering, enjoyed particular prestige within the institution ${ }^{16}$. In contrast to higher education in China today, Peiyang University students were allowed to change their major at any time during their first or second year of study. This flexibility allowed students to explore their 
personal interests and gave them more control over their learning. During summer vacations, students also had opportunities to go on field trips with their instructors to factories and mines.

The selection of both instructors and students at Peiyang University was strict thus maintaining the quality of the institution. All advanced science and engineering courses were taught by foreign instructors who were mostly graduate students of well-known American universities such as Stanford and MIT. These individuals had been recommended by their professors in response to a letter of invitation sent by Tenney Charles Daniel, the first Acting President or Provost of Peiyang University ${ }^{19}$. Famous Chinese experts and scholars were also hired, such as Mao Yisheng, a civil engineer who managed the construction of the first Chinese-built bridge. Students had to pass strict entrance exams to gain admission to Peiyang University. After admission, students faced further pressure: if they did not perform well, they were expelled. The performance of each student was evaluated by the instructors upon completion of their first year of study to determine if they were capable of more advanced studies. In a memoir about his experience as a student at Peiyang University, Chen Lifu wrote, "We had 45 students when we entered the university, but there were only 31 left upon graduation. Sixteen of them majored in civil engineering, and 15 of them majored in mining. Those who failed to graduate left either because they were ill, or because they were not qualified to pass the exam. In this way, one third of the students were cut from my class." 20 Since Peiyang University selected students based on quality and not on a student's social status, many students from poor families had the opportunity to receive a good education. This represented progress in China where, at the time, social status tended to dictate a person's future.

\section{Conclusions}

The three stories different institutions of higher education founded during the final years of the Qing Dynasty provide a picture of the development of modern engineering education in China. The Qing government was reluctant to reform a rigid system of social stratification and adopt Western science and technology. However, a string of humiliating military defeats forced China to introduce reform and establish institutions to teach Western learning in an attempt to bolster defenses against foreign incursion. Just as the original Confucian educational system in China was developed to prepare students to serve national interests, early engineering education in China was also developed to serve national interests. As with the first institutions to provide engineering education in France and the United States, the early development of engineering education in China focused on military applications.

The long tradition of engineering education at Peiyang University is still alive today, although with a new name. The institution was renamed Tianjin University in 1951. As one of the top universities in China, Tianjin University has turned out more than 150,000 graduates over the past hundred years ${ }^{18}$. These graduates form part of the backbone of manufacturing and industry in modern China. 


\section{References}

1. $\quad$ http://www.moe.gov.cn/edoas/website18/level2.jsp?tablename=1020

2 http://www.asee.org/publications/profiles/upload/2008ProfileEng.pdf

3. Hart, D., "Managing the global talent pool: Sovereignty, treaty, and intergovernmental networks," Technology in Society, vol. 28, pp. 421-434, 2006.

$4 \quad$ http://www.mpiwg-berlin.mpg.de/CHINA/intro_qq_ts.html

5. Lundgreen, P., "Engineering education in Europe and the USA, 1750-1930: The rise to dominance of school culture and the engineering professions," Annals of Science, vol. 33, pp. 33-75, 1990.

6. Marsh, R.M., The Mandarins: the circulation of elites in China, 1600-1900: Arno Press Inc., 1980.

7. Biggerstaff, K., The Earliest Modern Government Schools in China. Ithaca, NY: Cornell Univesity Press, 1961.

8. Needham, J., Science in Traditional China: A Comparative Perspective. Cambridge, MA: Harvard University Press, 1981.

9. Elman, B.A., A cultural history of civil examinations in late imperial China. Berkeley and Los Angeles, CA: University of California Press, 2000.

10. Miyazaki, I., China's examination hell: the civil service examinations of Imperial China. New Haven, CT: Yale University Press, 1981.

11. Yao, X., An Introduction to Confucianism. Cambridge: Cambridge University Press, 2000.

12. Hanes III, W.T. and F. Sanello, "The Opium Wars: The Addiction of One Empire and the Corruption of Another," Naperville, IL: Sourcebooks, Inc., 2002.

13. Spence, J.D., God's Chinese Son. New York, NY: W.W. Norton \& Company, 1996.

14. Beasley, W.G., The Meiji Restoration. Standford, CA: Stanford University Press, 1972.

15. Paine, S.C.M., The Sino-Japanese War of 1894-1895: perceptions, power, and primacy. Cambridge: Cambridge University Press, 2003.

16 Leonard, Jane Kate. Wei Yüan and China's Rediscovery of the Maritime World. Cambridge, MA: Council on East Asian Studies, 1984

17 Zhongguo jin dai jiao yu shi zi liao hui bian: Yang wu yun dong shi qi jiao yu, edited by Chen,Yuanhui, Chen, Xuexun and Tian, Zhengping [et al.]. Shanghai Educational Publish, Shanghai, 2007

18. Zong, W. and B. Zhang, "Pioneering Work in Chinese Modern Education History: the Foundation of Peiyang University and the Significance of Its Foundation," Journal of Tianjin University, 2005.

19. Office of Historical Records Tianjin University, Peiyang University: Tianjin University Historical Material Editing and Compiling: Tianjin University Press, 1991.

20. Chen, L., Reflection of Success and Failure: Memoir of Chen Lifu. Taipei: Zhengzhong Press, 1994.

21. http://www.tju.edu.cn/english/abouttju/ 